\title{
Green Synthesis of New Pyrrolo [1,2-a] quinoxalines as Antiproliferative Agents in GPER-expressing Breast Cancer Cells
}

\author{
Gabriele Carullo $\mathbb{D}^{1},{ }^{1}$ Sarah Mazzotta $\mathbb{D}^{2},{ }^{2}$ Francesca Giordano, ${ }^{3}$ and Francesca Aiello $\mathbb{D}^{3}$ \\ ${ }^{1}$ Department of Biotechnology, Chemistry and Pharmacy, DoE 2018-2022, University of Siena, Via Aldo Moro 2, \\ Siena 53100, Italy \\ ${ }^{2}$ Department of Pharmaceutical Sciences, University of Milan, Via Luigi Mangiagalli 25, Milano 20133, Italy \\ ${ }^{3}$ Department of Pharmacy, Health and Nutritional Sciences, DoE 2018-2022, University of Calabria Edificio Polifunzionale, \\ Arcavacata di Rende (CS) 87036, Italy
}

Correspondence should be addressed to Francesca Aiello; francesca.aiello@unical.it

Received 21 February 2021; Accepted 29 September 2021; Published 31 October 2021

Academic Editor: Lutfun Nahar

Copyright (c) 2021 Gabriele Carullo et al. This is an open access article distributed under the Creative Commons Attribution License, which permits unrestricted use, distribution, and reproduction in any medium, provided the original work is properly cited.

4,5-Dihydropyrrolo [1,2-a]quinoxalines are interesting druggable scaffolds, with multifaceted biological properties, including anticancer properties targeting the G protein-coupled estrogen receptor 1 (GPER). In this work, the synthesis and preliminary antiproliferative activity of a small set of new 4,5-dihydropyrrolo[1,2-a]quinoxalines (18-20) and pyrrolo[1,2-a]quinoxalines $(21,22)$ has been reported, inspired by known antiproliferative agents (G-1, G-15, and G-36). The synthesis of the pyrroloquinoxalinic core was employed following the Pictet-Spengler reaction, using the surfactant $p$-dodecylbenzene sulphonic acid ( $p$-DBSA), as catalyst. It demonstrated efficiency in the catalysis of the 4-phenylpyrrole [1,2-a] quinoxaline type compound formation in mild solvents such as water, ethanol, and hydroalcoholic solutions. In addition, the reactions proceeded in a short time (between 15 and 120 minutes) at room temperature and with high yields. The in vitro MTT assays showed that the presence of isopropyl groups furnished promising antiproliferative compounds. Although, the acetyl group provided also antiproliferative effects, breaking down its responsibility in the GPER transactivation. Nevertheless, it is possible to conclude that the 4,5-dihydropyrrolo[1,2-a]quinoxalines remain a feasible scaffold to develop anticancer agents against GPER-expressing cells.

\section{Introduction}

Heterocycles are organic cyclic compounds in which one of the positions of the ring is a heteroatom. They represent the most important class of biologically active compounds, both from synthetic and natural sources [1]. Over the years, nitrogen heterocycles emerged as interesting scaffolds in organic and medicinal chemistry applications. In particular, they showed different biological properties, becoming innovative tools for the development of new therapeutic entities [2]. In this field, several aromatic and aliphatic nitrogen heterocycles have been reported as antibacterials [3], antivirals $[4]$, anticancer $[5,6]$, anti-inflammatory $[7,8]$, and antihypertensive [9], among others [10]. Pyrrole is a fivemembered aromatic ring, widely present in a variety of biological contexts, as a xenobiotic or cofactor. In synthetic products, the pyrrole nucleus could be present as single/ substituted/condensed rings, as linker between different moieties, although it can be directly associated with biological targets [11]. These peculiarities prompted synthetic chemists to explore not only efficient synthetic methods such as Paal-Knorr, Huisgen, and Hantzsch reactions but also innovative approaches including multicomponent and green processes $[12,13]$. Pyrrole derivatives are privileged structures in medicinal chemistry due to the uncountable pharmacological profiles [14]. Among the activities, the anticancer one has been described for different types of pyrrole derivatives $[14,15]$. The $N$-substituted pyrroles represent an extended family of derivatives, recognized as anticancer tools. In particular, a set of pyrrole-3- 
carboxamide derivatives showed interesting antiproliferative effects in leukemia and pulmonary cell lines (such K562 and A549). The best compound 1 (Figure 1), derived from an intense structure-activity relationship (SAR) study, showed a low potency but high selectivity towards different tumor suppressors downstreams [16]. Furthermore, symmetrically substituted pyrroles were simply synthesized and evaluated as apoptotic agents in colorectal HCT116 and leukemic HL60 cells. The compounds, including 2 (Figure 1), induced time- and dose-dependent cell cycle arrest at the $G_{0} / G_{1}$ phase, although the corresponding pyrrolidines resulted more active [17]. Over the years, the search of new strategies for cancer therapy prompted us to investigate several pyrrole-based compounds, evaluating also new and efficient synthetic approaches [18-21]. The benzo-pyrrolo-oxazine derivative 3 (Figure 1 ) showed a limited activity in MDAMB-231 triple negative breast cancer cells (TNBCs) [22]; the corresponding analogue 4 , in which the biphenyl system, deprived of amide function, is appended in position 5, showed a better activity inducing apoptosis via poly (ADPribose) polymerase (PARP) cleavage [23]. In the field of proapoptotic agents, another class of pyrrole-based compounds is represented by pyrrolo-1,5-benzoxazepine 5 and pyrrolo-naphthoxazepine 6 (Figure 1). Moreover, 5 induced mitotic block and the onset of apoptosis in several cancer cell lines, while 6 resulted to be more druggable than 5 due to its pharmacokinetic properties and acted as a caspase 3-mediated apoptotic agent, interfering also with autophagic processes $[24,25]$. Condensed pyrrole derivatives were also investigated by us focusing development of differently substituted pyrrolo[1,2-a]quinoxalines, extensively explored in breast cancer models. One of the first synthesized compounds 7 (Figure 1), consisting of a pyrroloquinoxaline skeleton embedded with a pyrazinylhydrazide moiety, displayed significant in vivo efficacy in mice xenograft models [26]. Recently, we described new analogues, in which the aromatic ring is directly connected to the pyrroloquinoxaline nucleus. Compound 8, assayed in MDA-MB-231 cell line, highlighted the formation of autophagic vacuoles, in line with compound 6 [27]. Similarly, compound 9 induced a pronounced apoptosis in SKBR3 cells, compared to MCF-7, emphasizing the role of this type of compound in the most aggressive TNBC (Figure 1) [28]. Based on these promising data, in this work, we reported the synthesis and preliminary antiproliferative activity of a small set of new 4,5-dihydropyrrolo[1,2-a]quinoxalines $18-20$ and pyrrolo[1,2-a] quinoxalines 21, 22, inspired by known antiproliferative agents (G-1, G-15, and G-36) (Figure 1). G-1, chemically known as $1-((3 \mathrm{aS}, 4 \mathrm{R}, 9 \mathrm{bR})-4$-(6-bromobenzo $[d][1,3]$ dioxol-5-yl)-3a,4,5,9b-tetrahydro-3H-cyclopenta[c]quinolin-8-yl)ethan-1-one, a potent and selective GPER agonist $\left(K i=11 \mathrm{nM}, \mathrm{EC}_{50}=2 \mathrm{nM}\right)$, displays no activity at $\operatorname{ER} \alpha$ and $\operatorname{ER} \beta$ at concentrations up to $10 \mu \mathrm{M}$. It also increases intracellular calcium levels and inhibits the migration of SKBR3 and MCF-7 cells in response to chemoattractants $\left(\mathrm{IC}_{50}\right.$ values are 0.7 and $1.6 \mathrm{nM}$, respectively) in vitro. G-15 is a high affinity and selective GPER antagonist with $\mathrm{Ki}$ of $20 \mathrm{nM}$. The compounds described here derived from two building blocks 16 and
17. These precursors are decorated with acetyl and isopropyl moieties, respectively, also found in 5, 6, 11, and other antiproliferative agents. The pending phenyl ring was modified with methylenedioxo or vanillic portions, as in compounds 8 and 9 (Figure 1).

\section{Materials and Methods}

2.1. Chemistry. All reagents were purchased from Merck and used without further purification. Solvents were dried and distilled according to conventional procedures [29]. Anhydrous reactions were carried out under argon atmosphere, monitored by thin layer chromatography (TLC) on silica gel plates (Merck 60F254, $0.2 \mathrm{~mm}$ ) and visualized by UV light at 254 and $366 \mathrm{~nm}$ of wavelength. Organic solutions were dried over anhydrous $\mathrm{Na}_{2} \mathrm{SO}_{4}$ and evaporated on a rotary evaporator under reduced pressure. Final compounds were purified by flash chromatography columns on silica gel (Merck, 60, 230-400 mesh, $0.040-0.063 \mathrm{~mm}$ ). Melting points were obtained by a GallenKamp21374 apparatus and were uncorrected. ${ }^{1} \mathrm{H}$ NMR and ${ }^{13} \mathrm{C}$-NMR spectra were recorded on a Bruker $300 \mathrm{MHz}$ spectrometer. Chemical shifts $(\delta)$ were reported in ppm, using tetramethylsilane (TMS) as the internal reference standard. Coupling constants were reported as $J$ values in Hertz $(\mathrm{Hz})$, and the number of protons is indicated parenthetically. Mass spectra data were determined after electron impact ionization at $70 \mathrm{eV}$ on the $\mathrm{HP}$ 5973MS spectrometer. Elemental analyses were performed on LECO TruSpec CHNS Microelemental system (St. Joseph, MI, USA). The purity of the final compounds was evaluated by $\mathrm{C}, \mathrm{H}, \mathrm{N}$ analysis, and it was confirmed to be $\geq 95 \%$. Yields refer to purified products and are not optimized.

2.1.1. Synthesis of N-(5-Acetyl-2-nitrophenyl)acetamide (11). To a cooled mixture $\left(0-5^{\circ} \mathrm{C}\right)$ of fuming nitric acid $(0.5 \mathrm{~mL})$ and acetic anhydride $(1 \mathrm{~mL})$, the commercially available $N$ (3-acetylphenyl)acetamide 10 was added. The reaction was stirred for $10 \mathrm{~min}$, and then, ice was added to the mixture. The obtained solution was neutralized with aqueous $\mathrm{K}_{2} \mathrm{CO}_{3}$ and extracted with $\mathrm{CHCl}_{3}$. The organic phase was dried over $\mathrm{Na}_{2} \mathrm{SO}_{4}$ and concentrated under reduced pressure. The pure compound 11 was isolated by flash chromatography using chloroform: diethyl ether $(1: 1)$ as eluent. Yellow crystals (18\% yield); m.p. $121^{\circ} \mathrm{C} .{ }^{1} \mathrm{H}-\mathrm{NMR}\left(\mathrm{CDCl}_{3}\right) \delta: 10.21$ (bs, $\left.1 \mathrm{H}\right)$, $9.28(\mathrm{~d}, 1 \mathrm{H}, J=1.8 \mathrm{~Hz}), 8.20(\mathrm{~d}, 1 \mathrm{H}, J=8.8 \mathrm{z}), 7.65(\mathrm{dd}$, $J=1.9 \mathrm{~Hz} J=8.8 \mathrm{~Hz}$ ), $2.60(\mathrm{~s}, 3 \mathrm{H})$, and 2.25 (s, 3H). MS (EI): $m / z 222[\mathrm{M}]^{+}$.

2.1.2. Synthesis of 1-(4-Nitro-3-(1H-pyrrol-1-yl)phenyl) ethan-1-one (12). Compound $11(3.15 \mathrm{mmol})$ was suspended in $6 \mathrm{~N}$ aqueous $\mathrm{HCl}(10 \mathrm{~mL})$, and the mixture was heated at $120^{\circ} \mathrm{C}$ for $4 \mathrm{~h}$. Then, the reaction was cooled to $0^{\circ} \mathrm{C}$ and neutralized with aqueous $\mathrm{NaOH} 50 \% \mathrm{~m} / \mathrm{V}$. The compound 1-(3-amino-4-nitrophenyl)ethan-1-one was obtained after precipitation as red crystals and used without further purification (MS (EI): $m / z \quad 180[\mathrm{M}]^{+}$). This intermediate 

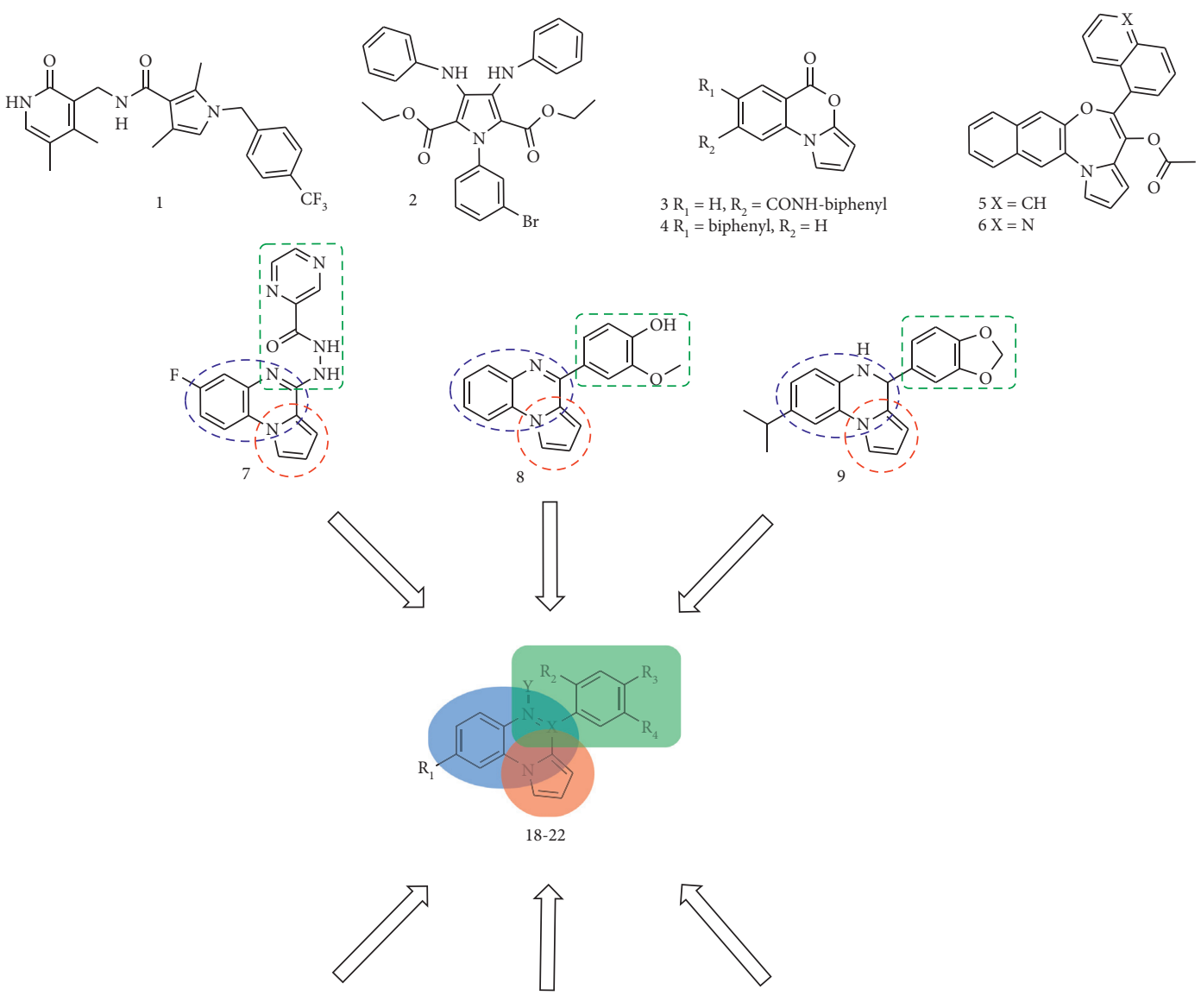

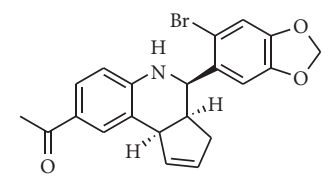

G-1

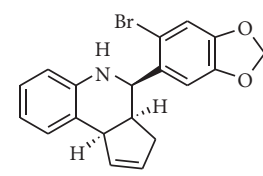

G-15

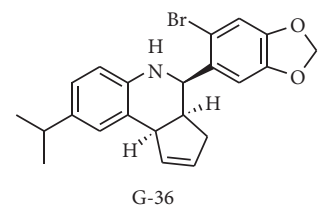

Figure 1: Design of new pyrrolo-[1,2-a]quinoxalines.

( $2.77 \mathrm{mmol})$ was added to a hot solution of 4-chloropyridine hydrochloride $(2.77 \mathrm{mmol})$ and 2,5-dimethoxytetrahydrofuran $(3.32 \mathrm{mmol})$ in 1,4 -dioxane $(7 \mathrm{~mL})$. The resulting mixture was stirred at $150^{\circ} \mathrm{C}$ for $1 \mathrm{~h}$, cooled to room temperature, and filtered using Celite ${ }^{\circledR}$. The pure compound 12 was isolated by flash chromatography using $n$-hexane : ethyl acetate $(3: 1)$ as eluent. Orange oil ( $89 \%$ yield). ${ }^{1} \mathrm{H}-\mathrm{NMR}$ $\left(\mathrm{CDCl}_{3}\right) \delta: 8.04-8.02(\mathrm{~m}, 1 \mathrm{H}), 8.00(\mathrm{~d}, 1 \mathrm{H}, J=2.0 \mathrm{~Hz}), 7.91$ $(\mathrm{dd}, 1 \mathrm{H}, J=0.55 \mathrm{~Hz}, J=8.2 \mathrm{~Hz}), 6.83(\mathrm{t}, 2 \mathrm{H}, J=2.1 \mathrm{~Hz}), 6.40$ $(\mathrm{t}, 2 \mathrm{H}, J=2.2 \mathrm{~Hz})$, and $2.70(\mathrm{~s}, 3 \mathrm{H})$. MS (EI): $\mathrm{m} / z 230[\mathrm{M}]^{+}$.

2.1.3. Synthesis of 2-Bromo-4-isopropyl-1-nitrobenzene (14). To a cold solution $\left(0^{\circ} \mathrm{C}\right)$ of dry toluene $(20 \mathrm{~mL}), 2$-bromo-4isopropylaniline $(13,2.33 \mathrm{mmol})$ was added. This mixture was stirred for $10 \mathrm{~min}$, and then, $m$-chloroperbenzoic acid ( $m$-CPBA, $16.9 \mathrm{mmol}$ ) was added. The resulting solution was refluxed for $24 \mathrm{~h}$, cooled to room temperature, filtered in vacuum, and washed with fresh toluene. The liquid residue was diluted with diethyl ether and extracted with 10\% aqueous $\mathrm{NaOH}$. The organic layer was dried over $\mathrm{Na}_{2} \mathrm{SO}_{4}$, filtered, and evaporated. The pure compound 14 was isolated by flash chromatography using $n$-hexane/dichloromethane $(4: 1)$ as eluent. Yellow oil. $70 \%$ yield. Spectroscopic data agree with those published [30].

2.1.4. 1-(5-Isopropyl-2-nitrophenyl)-1H-pyrrole (15). Acetonitrile $(24 \mathrm{~mL})$ was added to a mixture of 14 $(1.64 \mathrm{mmol})$, pyrrole $(8.2 \mathrm{mmol})$, potassium iodide $(1.97 \mathrm{mmol})$, copper powder $(1.64 \mathrm{mmol})$, and cesium carbonate $(3.28 \mathrm{mmol})$. The resulting suspension was refluxed for $48 \mathrm{~h}$, cooled to room temperature, and filtered in vacuum. The residue was dried, and the pure compound 15 was isolated by flash chromatography using petroleum ether/ chloroform $(3: 1)$. Yellow oil (43\% yield). ${ }^{1} \mathrm{H}-\mathrm{NMR}\left(\mathrm{CDCl}_{3}\right)$ $\delta: 7.83(\mathrm{~d}, 1 \mathrm{H}, J=8.0 \mathrm{~Hz}), 7.34(\mathrm{~d}, 1 \mathrm{H}, J=1.8 \mathrm{~Hz}), 7.31(\mathrm{~s}$, $1 \mathrm{H}), 6.81(\mathrm{t}, 2 \mathrm{H}, J=2.0 \mathrm{~Hz}), 6.38(\mathrm{t}, 2 \mathrm{H}, J=2.1 \mathrm{~Hz}), 3.10-2.98$ $(\mathrm{m}, 1 \mathrm{H})$, and $1.35(\mathrm{~s}, 6 \mathrm{H})$. MS (EI) $\mathrm{m} / z: 230[\mathrm{M}]^{+}$.

2.1.5. General Procedure for the Synthesis of Anilines (16-17). Compound 12 or $15(2.47 \mathrm{mmol})$ was diluted in ethanol $96 \%$ $(16.5 \mathrm{~mL})$ and heated at $55^{\circ} \mathrm{C}$. Then, iron powder 
(9.91 mmol) and aqueous solution $(2 \mathrm{~mL})$ of ammonium chloride $(9.91 \mathrm{mmol})$ were added. The mixture was stirred at the same temperature for $1 \mathrm{~h}$, cooled to room temperature, and filtered using Celite ${ }^{\circledR}$. The residue was basified to $\mathrm{pH} 8$ by adding a saturated $\mathrm{NaHCO}_{3}$ solution and extracted with ethyl acetate $(3 \times 30 \mathrm{~mL})$. The organic layer was then dried, filtered, evaporated, and used without purification.

2.1.6. General Procedure for the Synthesis of Pyrrolo[1,2-a] quinoxalines (18-21). To a well-stirred solution of $p$-DBSA $(0.0291 \mathrm{mmol})$ in ethanol $96 \%(2 \mathrm{~mL})$, the aniline (16 or 17 , $0.291 \mathrm{mmol})$ and the corresponding aldehyde $(0.349 \mathrm{mmol})$ were added. The mixture was stirred for $15 \mathrm{~min}$ at room temperature, and the solvent was evaporated to dryness. The residue was diluted with ethyl acetate, washed with saturated $\mathrm{NaHCO}_{3}$ aqueous solution, and then with brine. The organic layer was dried over $\mathrm{Na}_{2} \mathrm{SO}_{4}$ and concentrated in vacuum. The pure compounds were obtained by flash chromatography using $n$-hexane/ethyl acetate (6:1 to $2: 1)$ as eluent.

1-(4-(6-Bromobenzo[d][1,3]dioxol-5-yl)-4,5-dihydropyrrolo [1,2-a]quinoxalin-8-yl)ethan-1-one (18). White solid (43\% yield); m.p. $225^{\circ} \mathrm{C} .{ }^{1} \mathrm{H}-\mathrm{NMR}\left(300 \mathrm{MHz}\right.$, acetone- $\left.d_{6}\right): \delta 8.00(\mathrm{~s}$, $1 \mathrm{H}), 7.54(\mathrm{dd}, 1 \mathrm{H}, J=1.8 \mathrm{~Hz}, J=8.3 \mathrm{~Hz}), 7.47-7.43(\mathrm{~m}, 2 \mathrm{H})$, $6.99(\mathrm{~s}, 1 \mathrm{H}), 6.85(\mathrm{~d}, 1 \mathrm{H}, J=8.4 \mathrm{~Hz}), 6.63(\mathrm{~s}, 1 \mathrm{H}), 6.17(\mathrm{t}, 1 \mathrm{H}$, $J=3.3 \mathrm{~Hz}$ ), 5.99 (s, 1H), 5.90 (d, 2H, J=1.8 Hz), 5.70 (bs, $1 \mathrm{H})$, $3.50(\mathrm{~s}, 3 \mathrm{H}) .{ }^{13} \mathrm{C}-\mathrm{NMR}\left(75 \mathrm{MHz}\right.$, acetone- $\left.d_{6}\right): \delta 193.9,147.4$, $147.1,139.4,134.2,126.0,125.2,122.6,114.7,114.2,113.8$, $113.5,113.3,111.6,108.2,107.4,105.2,101.4,53.0,24.4 . \mathrm{MS}$ (EI) $m / z: 410[\mathrm{M}]^{+}$. Anal. calcd. for $\mathrm{C}_{20} \mathrm{H}_{15} \mathrm{BrN}_{2} \mathrm{O}_{3}: \mathrm{C} 58.41, \mathrm{H} 3.68$, $\mathrm{N} 6.81 \%$ found C 58.40, H 3.65, N 6.83\%.

4-(6-Bromobenzo[d][1,3]dioxol-5-yl)-8-isopropyl-4,5-dihydropyrrolo[1,2-a]quinoxaline (19). Amber oil (56\% yield). ${ }^{1} \mathrm{H}$ NMR $\left(300 \mathrm{MHz}, \mathrm{CDCl}_{3}\right): \delta 7.22-7.20 \mathrm{~m}(1 \mathrm{H}), 7.01(\mathrm{~s}, 1 \mathrm{H})$, $6.85(\mathrm{~d}, 1 \mathrm{H}, J=7.5 \mathrm{~Hz}), 6.75(\mathrm{~s}, 1 \mathrm{H}), 6.67(\mathrm{~d}, 1 \mathrm{H}, J=8.2 \mathrm{~Hz})$, $6.30(\mathrm{t}, 1 \mathrm{H}, J=3.3 \mathrm{~Hz}), 6.09(\mathrm{~d}, 1 \mathrm{H}, J=6.7 \mathrm{~Hz}), 5.95(\mathrm{~s}, 2 \mathrm{H})$, 5.70 (bs, 1H), 4.28 (bs, 1H), 2.95-2.82 (m, 1H), 1.30 (s, 6H). ${ }^{13} \mathrm{C}-\mathrm{NMR}\left(75 \mathrm{MHz}, \mathrm{CDCl}_{3}\right): \delta 147.8,138.0,136.0,135.0$, $133.0,131.0,130.0,129.0,128.1,122.8,115.2,115.0,112.9$, $112.3,110.1,110.0,105.2,33.4,23.1$. MS (EI) $m / z: 410[\mathrm{M}]^{+}$. Anal. calcd. for $\mathrm{C}_{21} \mathrm{H}_{19} \mathrm{BrN}_{2} \mathrm{O}_{2}$ : $\mathrm{C}$ 61.33, $\mathrm{H}$ 4.66, N 6.81\% found $\mathrm{C} 61.35, \mathrm{H} 3.62, \mathrm{~N} 6.80 \%$.

4-(8-Isopropyl-4,5-dihydropyrrolo[1,2-a]quinoxalin-4yl)-2-methoxyphenol (20). Yellow solid (42\% yield); m.p.121-122 ${ }^{\circ} \mathrm{C} .{ }^{1} \mathrm{H}-\mathrm{NMR}\left(300 \mathrm{MHz}, \mathrm{CDCl}_{3}\right): \delta 7.32-7.21$ $(\mathrm{m}, 3 \mathrm{H}), 7.10(\mathrm{~d}, 1 \mathrm{H}, J=1.7 \mathrm{~Hz}) 7.05-6.94(\mathrm{~m}, 2 \mathrm{H})$, 6.92-6.85 (m, 1H), $6.76(\mathrm{~s}, 1 \mathrm{H}), 6.70-6.27(\mathrm{~m}, 2 \mathrm{H}), 6.27(\mathrm{t}$, $1 \mathrm{H}, J=3.1 \mathrm{~Hz}), 5.67$ (bs, $1 \mathrm{H}), 5.60$ (bs, $1 \mathrm{H}), 5.44$ (s, 1H), 3.90 (s, 3H), 3.00-2.82 (m, 1H), $1.35(\mathrm{~s}, 6 \mathrm{H}) ;{ }^{13} \mathrm{C}-\mathrm{NMR}(75 \mathrm{MHz}$, $\left.\mathrm{CDCl}_{3}\right): \delta 145.8,144.7,139.5,133.3,132.2,129.7,124.5$, $121.5,120.3,114.3,113.3,113.0,111.9,109.3,109.0,104.7$, 55.3, 55.0, 33.6, 23.3. MS (EI) $m / z: 332[\mathrm{M}]^{+}$. Anal. calcd. for $\mathrm{C}_{21} \mathrm{H}_{22} \mathrm{~N}_{2} \mathrm{O}_{2}$ : C 75.42, $\mathrm{H} 6.63, \mathrm{~N} 8.38 \%$ found $\mathrm{C} 75.50, \mathrm{H}$ 6.60, N 8.35\%.

1-(4-(4-Hydroxy-3-methoxyphenyl)pyrrolo[1,2-a]quinoxalin-8yl)ethan-1-one (21). Yellow solid (95\% yield); m.p.222 ${ }^{\circ} \mathrm{C} .{ }^{1} \mathrm{H}-$ NMR (300 MHz, $\left.\mathrm{CDCl}_{3}\right): \delta 8.50(\mathrm{~s}, 1 \mathrm{H}), 8.15-7.99(\mathrm{~m}, 3 \mathrm{H})$,
7.64-7.59 (m, 2H), 7.13-7.05 (m, 2H), 6.94 (dd, $1 \mathrm{H}, J=2.7 \mathrm{~Hz}$, $J=7.0 \mathrm{~Hz}), 6.20(\mathrm{bs}, 1 \mathrm{H}), 4.00(\mathrm{~s}, 3 \mathrm{H}), 2.80(\mathrm{~s}, 3 \mathrm{H}) ;{ }^{13} \mathrm{C}-\mathrm{NMR}$ $\left(75 \mathrm{MHz}, \mathrm{CDCl}_{3}\right): \delta 196.9,155.9,147.9,146.8,139.6,134.8$, $130.1,129.8,126.9,125.2,122.5,115.8,114.5,114.3,113.7$, 111.2, 110.1, 56.1, 26.7. MS (EI) $m / z: 332[\mathrm{M}]^{+}$. Anal. calcd. for $\mathrm{C}_{20} \mathrm{H}_{16} \mathrm{~N}_{2} \mathrm{O}_{3}$ : C 72.28, $\mathrm{H} 4.85, \mathrm{~N} 8.43 \%$ found $\mathrm{C} 75.20, \mathrm{H} 4.88$, N $8.46 \%$.

1-(4-Amino-3-(1H-pyrrol-1-yl)phenyl)ethan-1-one (16). Orange oil (81\% yield). ${ }^{1} \mathrm{H}-\mathrm{NMR}\left(\mathrm{CDCl}_{3}\right) \delta: 7.84(\mathrm{~d}, 1 \mathrm{H}$, $J=2.0 \mathrm{~Hz}), 7.81(\mathrm{~d}, 1 \mathrm{H}, J=1.9 \mathrm{~Hz}), 7.79(\mathrm{~d}, 1 \mathrm{H}, J=1.8 \mathrm{~Hz})$, $6.84(\mathrm{t}, 2 \mathrm{H}, J=2.0 \mathrm{~Hz}), 6.38(\mathrm{t}, 2 \mathrm{H}, J=2.1 \mathrm{~Hz}), 4.20$ (bs, $2 \mathrm{H})$, and $2.50(\mathrm{~s}, 3 \mathrm{H})$. MS (EI) $\mathrm{m} / z: 200[\mathrm{M}]^{+}$.

4-Isopropyl-2-(1H-pyrrol-1-yl)aniline (17). Yellow solid (70\% yield). ${ }^{1} \mathrm{H}-\mathrm{NMR}\left(300 \mathrm{MHz}, \mathrm{CDCl}_{3}\right) \delta: 6.95-6.85(\mathrm{~m}$, $2 \mathrm{H}), 6.73(\mathrm{t}, 2 \mathrm{H}, J=3.9 \mathrm{~Hz}), 6.61(\mathrm{~d}, 1 \mathrm{H}, J=8.5 \mathrm{~Hz}), 6.23(\mathrm{t}$, $2 \mathrm{H}, J=3.8 \mathrm{~Hz}), 3.40(\mathrm{bs}, 2 \mathrm{H}), 2.70(\mathrm{~m}, 1 \mathrm{H}), 1.15(\mathrm{~s}, 3 \mathrm{H})$, and $1.10(\mathrm{~s}, 3 \mathrm{H})$.

\subsection{Biological Evaluation}

2.2.1. Reagents. The following components were obtained from the respective companies, with their addresses in brackets. DMEM/F-12, Dulbecco's modified Eagle's medium, RPMI medium, L-Glutamine, penicillin/streptomycin, Dulbecco's Phosphate Buffer Saline were purchased from by Invitrogen (Carlsbad, CA, USA). MTT, dimethyl sulphoxide, and propidium iodide are from Sigma (Milan, Italy).

2.2.2. Cell Cultures. MCF-7 and SKBR3 breast cancer cells were obtained from the American Type Culture Collection (ATCC) (Manassas, VA). MCF-7 cells were cultured in DMEM-F12 containing 5\% fetal bovine serum, 1\% L-glutamine, and $1 \mathrm{mg} / \mathrm{ml}$ penicillin-streptomycin. SKBR3 cells were maintained in complete RPMI supplemented with $10 \%$ fetal bovine serum, $1 \%$ L-glutamine, and $1 \mathrm{mg} / \mathrm{ml}$ penicillin-streptomycin.

2.2.3. DNA Flow Cytometry. To determine cell cycle distribution analysis, cells were harvested by trypsinization, fixed, and stained with propidium iodide $(100 \mathrm{~g} / \mathrm{mL})$ after treatment with RNase A $(20 \mathrm{~g} / \mathrm{mL})$. The DNA content was measured using a FACScan flow cytometer (Becton Dickinson, Mountain View, CA, USA), and the data were acquired using Cell Quest software. Cell cycle profiles were determined using ModFit LT.

\section{Results and Discussion}

3.1. Chemistry. The synthesized compounds, characterized by a 4,5-dihydropyrrolo[1,2-a]quinoxaline scaffold $(18,19)$ and a pyrrolo[1,2-a]quinoxaline scaffold $(20,21)$ were synthesized using the Pictet-Spengler condensation. For the synthesis of anilines 16 and 17, two different synthetic pathways were employed (Figure 2). In the case of 16, the commercially available 3 -acetamido acetophenone (10) was nitrated in the presence of the nitrating couple fuming nitric 


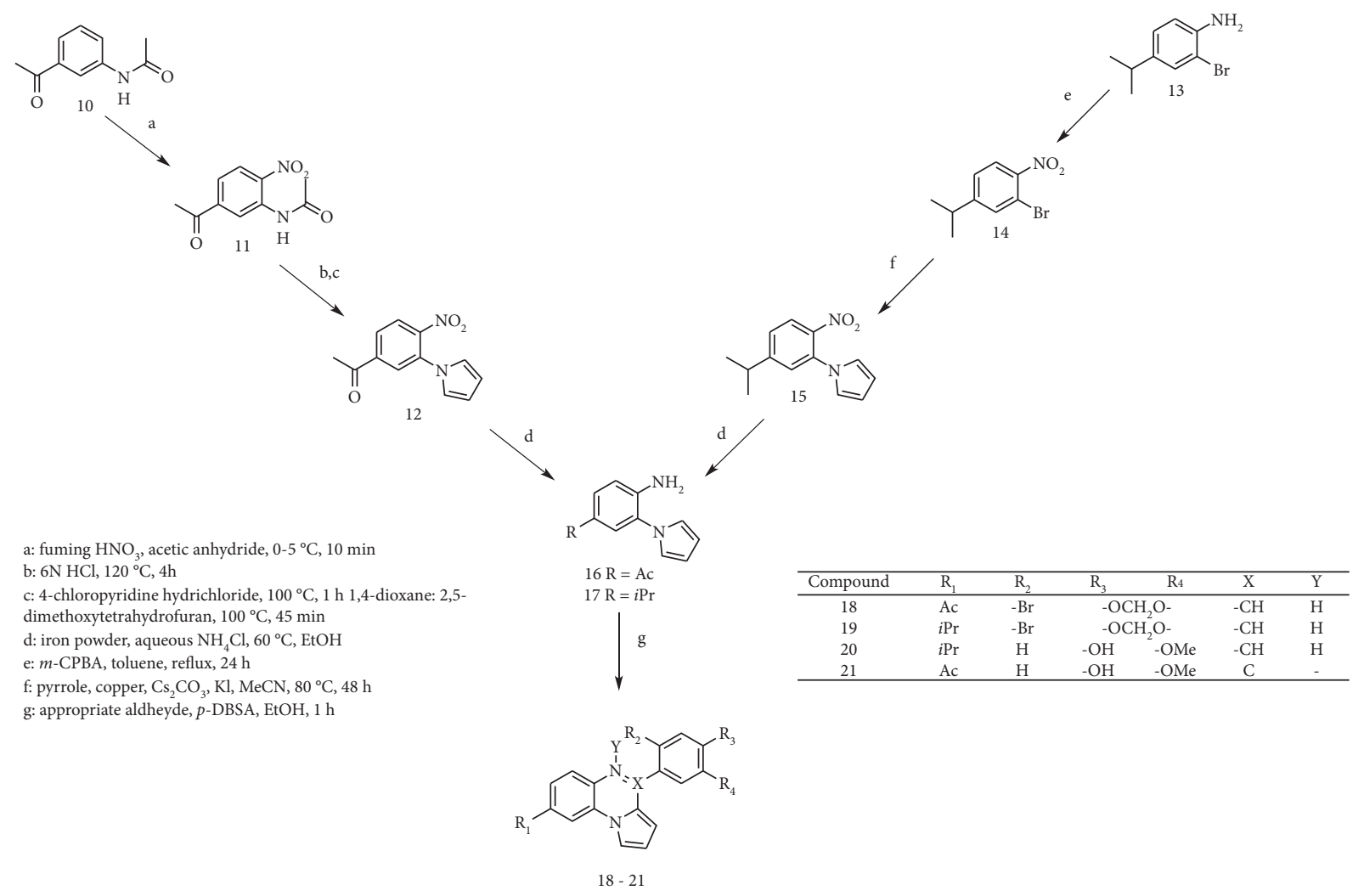

Figure 2: Synthesis of compounds 18-21.

acid/acetic anhydride, furnishing a mixture of regioisomers from which the compound 11 was isolated for further modifications. The acetamido function of 11 was hydrolyzed in acidic conditions $(6 \mathrm{~N} \mathrm{HCl})$ to obtain the aniline derivative that was available for the Clauson-Kass reaction to obtain the pyrrole one 12. Then, 12 was reduced in the presence of iron powder and ammonium chloride in ethanol to afford the final aniline intermediate 16 . On the other hand, for the synthesis of 17, 2-bromo-4-isopropylaniline 13 was first oxidized in the presence of $m$-CPBA in toluene. The intermediate 14 was then reacted with pyrrole under Ullmann conditions in the presence of copper powder, potassium iodide, and cesium carbonate. The nitro group of compound 15 was then reduced to aniline 17 in the same conditions described for 16. Both derivatives 16 and 17 were subjected to the Pictet-Spengler reaction with the aim of obtaining the final compounds 18-21 (Figure 2). The copy of original GCMS and NMR spectra of final compound $18-21$ are reported in Figures S1-S8 in Supplementary Materials. The Pictet-Spengler reaction was born in 1911 from two chemists Amé Pictet and Theodor Spengler who synthesized, for the first time, tetrahydroisoquinolines. This method consists in the condensation of a $\beta$-arylenylamine with an aldehyde or a ketone in acid catalysis. The mechanism involves the initial protonation of the carbonyl oxygen by the acid; this intermediate was then subjected to the nucleophilic substitution by the amine, furnishing a Schiff base with the contemporary release of a water molecule. The iminic intermediate therefore undergoes a 6-endo-trig cyclization with loss of aromaticity. The final deprotonation restores the aromaticity and provides the tetrahydroisoquinoline core. Some variants involve the use of Lewis acids as catalysts. Generally, this procedure involved harmful organic solvents such as tetrahydrofuran, acetonitrile, and toxic catalysts such as aluminium chloride, with low yields. Based on recent studies that use surfactants as catalysts for chemical reactions, $p$-dodecylbenzenesulfonic acid ( $p$-DBSA) was evaluated as a green and potential catalyst for the Pictet-Spengler reaction. It demonstrated efficiency in the catalysis of the 4-phenylpyrrole $[1,2-a]$ quinoxaline type compound formation in mild solvents such as water, ethanol, and hydroalcoholic solutions. In addition, the reactions proceeded in short time (between 15 and 120 minutes) at room temperature and with high yields. In this work, different arylaldehydes such 6-bromopiperonal and vanillin were used to introduce the pursued chemical diversity by different types of substituents. p-DBSA was used as an efficient catalyst providing compounds in short time (from 30 to 90 minutes) in ethanol as solvent.

3.2. BiologicalEvaluation. First, we investigated the effects of four synthetic compounds on breast cancer cell viability, by using SKBR3 cells $\left(\mathrm{GPER}^{+}, \mathrm{ER} \alpha^{-}\right.$, and ER $\beta^{-}$) and MCF-7 cells $\left(\mathrm{GPER}^{+}, \mathrm{ER} \alpha^{+}\right.$, and $\left.\mathrm{ER} \beta^{+}\right)$. These cells were treated with $1 \mu \mathrm{M}$ of compounds $18-21$ for 24 and $48 \mathrm{~h}$, by using the MTT assay. The selected dose was used to be in line with our previous experiments [28]. As shown in Figure 3, a significant decreasing in cell viability was observed after $24 \mathrm{~h}$ and $48 \mathrm{~h}$ of treatment, respectively, with compounds 19 and 20 in SKBR3 cells. 
MCF-7

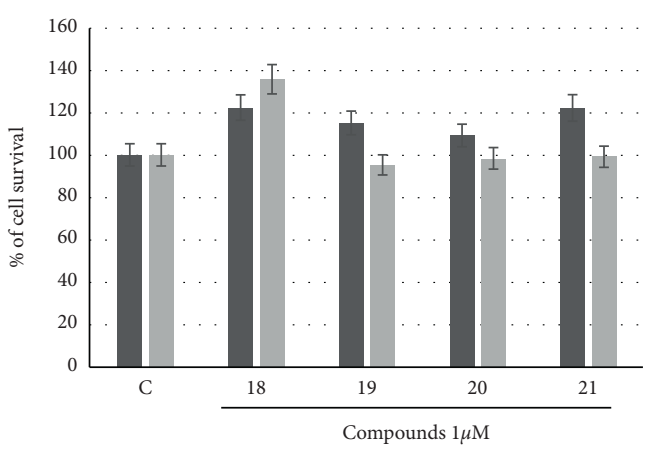

- $24 \mathrm{~h}$

- $48 \mathrm{~h}$<smiles>CC(=O)c1ccc2nc(-c3cc4c(cc3Br)OCO4)c3cccn3c2c1</smiles>

18

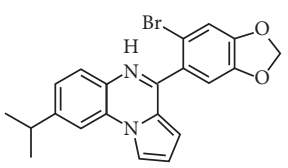

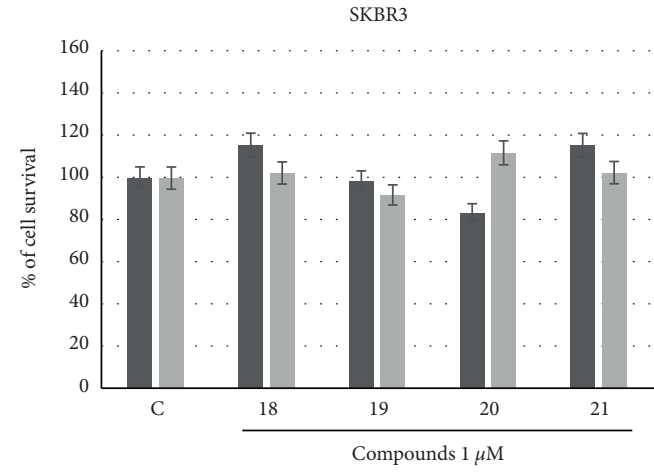

- $24 \mathrm{~h}$<smiles>COc1cc(-c2nc3ccc(C(C)C)cc3n3cccc23)ccc1O</smiles>

20<smiles>COc1cc(-c2nc3ccc(C(C)=O)cc3n3cccc23)ccc1O</smiles>

21

FIGURE 3: Effects compounds on breast cancer growth. MTT growth assays in MCF-7 and SKBR3 cells were treated with $1 \mu \mathrm{M}$ of $18,19,20$, and 21 compounds for 24 and 48 hours. Untreated cells are denoted with control (C). Cell proliferation is the representative of three different experiments, each performed in triplicate.

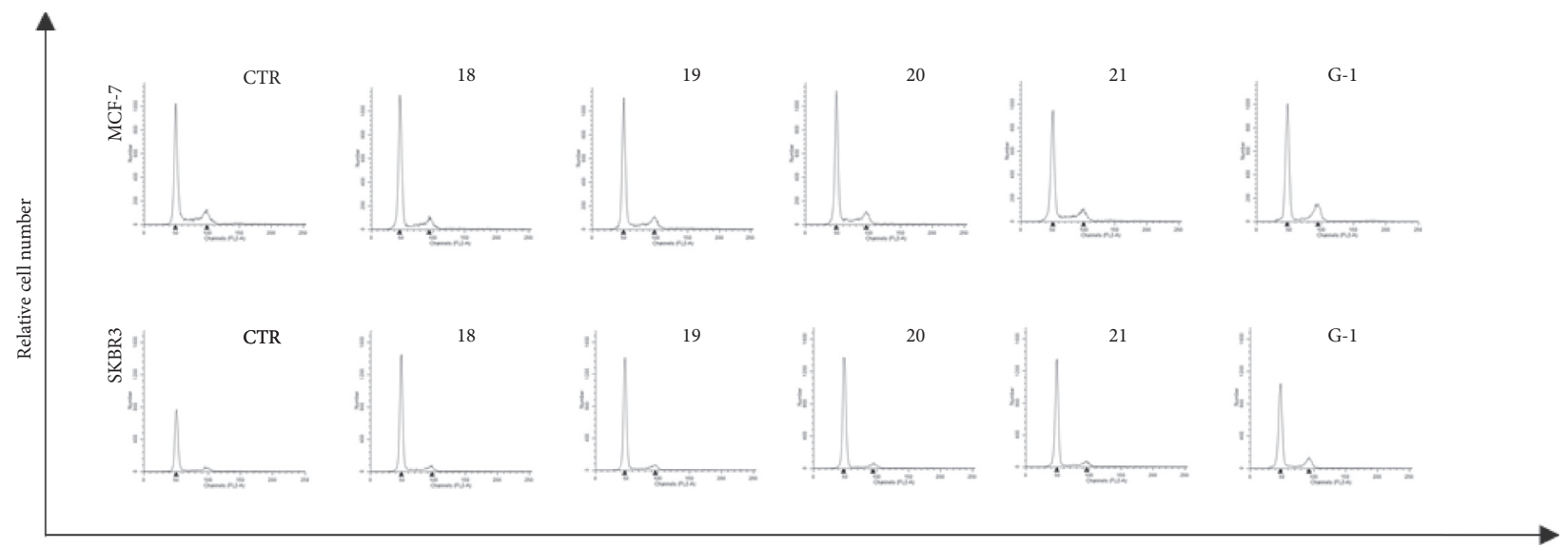

(a)

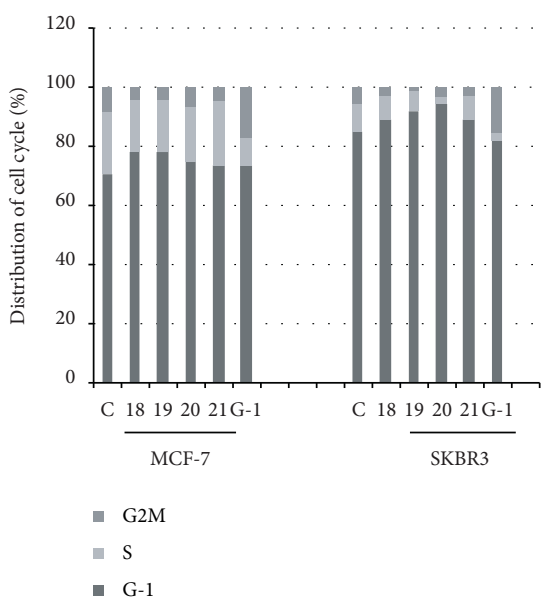

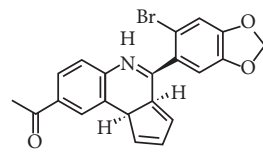

G-1

(b)

FIgURE 4: Effects of compounds 18, 19, 20, 21, and G-1 on cell cycle distribution in breast cancer cells. (a) MCF-7 and SKBR3 cells treated with $1 \mu \mathrm{M}$ of compounds as indicated for $48 \mathrm{~h}$, stained with propidium iodide (PI), and analyzed on a FACScan flow cytometer. (b) Quantitative analysis of percentage gated cells at G1, S, and G2/M phases were shown. 
To determine whether the cell growth inhibition induced by the compounds was a consequence of cell cycle perturbations, under the same experimental conditions, the flow cytometric cell cycle analysis in MCF-7 and SKBR3 breast cancer cells was performed. The results obtained showed an increase in the G1 phase and a concomitant reduction of cell population in S-phase, compared to untreated cells, especially in SKBR3 cells treated with compounds 19 and 20. Otherwise, in MCF-7 cells was not observed any change (Figure 4), probably involving a GPER-mediated activity.

GPER is known to mediate rapid nongenomic signals of estrogens, modulating their responsiveness and development and/or progression of $\mathrm{ER}^{-}$breast cancers. Numerous studies demonstrated that activation of GPER by its specific synthetic agonist G-1 results in cell cycle arrest and proliferation inhibition of $\mathrm{ER} \alpha^{+}$breast cancer [31], endothelial cells [32], prostate [33], and ovarian [34] cancer cells. Different studies suggest that GPER could be an excellent new therapeutic target for the treatment of $\mathrm{ER}^{-}$breast cancer [35]. Our preliminary results demonstrated that compounds 19 and 20 could represent the most promising GPER ligands endowing with specific anticancer activity in SKBR3 cells. From the chemical point of view, 19 shows the 6-bromobenzodioxolyl moiety typical of both GPER antagonists G-15 and G-36 and the agonist G-1. 20 lacks this motif to show instead a vanillyl one that could be featured as an opened form of dioxole. Both are decorated on C8 position with an isopropyl group, present in the GPER antagonist G-36.

\section{Conclusions}

Pyrrole-based compounds showed to be harmful pharmaceutical agents, able to interfere with different biological systems. Diversified derivatives demonstrated suitable anticancer properties. In this study, the small number of compounds does not allow to perform a deep SAR study. Overall, the pyrroloquinoxaline scaffold is demonstrated to be an interesting tool for the development of new antiproliferative agents. The presence of isopropyl groups furnished good antiproliferative compounds in line with the better activity exerted by G-36 compared to G-15. Although, the acetyl group provided also antiproliferative effects, breaking down its responsibility in the GPER transactivation. Nevertheless, it is possible to conclude that the 4,5-dihydropyrrolo[1,2-a]quinoxalines remains a feasible scaffold to develop anticancer agents against GPERexpressing cells.

\section{Data Availability}

The data used to support the findings of this study are included within the article.

\section{Disclosure}

Gabriele Carullo and Sarah Mazzotta are the co-first authors.

\section{Conflicts of Interest}

The authors declare that they have no conflicts of interest.

\section{Acknowledgments}

The authors from Department of Pharmacy, Health and Nutritional Sciences, University of Calabria and authors from Department of Biotechnology, Chemistry and Pharmacy, University of Siena wish to thank Ministero dell'Istruzione, delll'Universitá e della Ricerca for the grant "Dipartimento di Eccellenza 2018-2022" (L. 232/2016).

\section{Supplementary Materials}

Copies of MS(EI), ${ }^{1} \mathrm{H}-\mathrm{NMR}$, and ${ }^{13} \mathrm{C}-\mathrm{NMR}$ spectra (S1-S8). (Supplementary Materials)

\section{References}

[1] R. Dua, S. Shrivastava, S. K. Sonwane, and S. K. Srivastava, "Pharmacological significance of synthetic heterocycles scaffold: a review," Advances in Biological Research, vol. 5, pp. 120-144, 2011.

[2] N. Kerru, L. Gummidi, S. Maddila, K. K. Gangu, and S. B. Jonnalagadda, "A review on recent advances in nitrogencontaining molecules and their biological applications," Molecules, vol. 25, 2020.

[3] S. Mazzotta, T. Cebrero-Cangueiro, L. Frattaruolo et al., "Exploration of piperazine-derived thioureas as antibacterial and anti-inflammatory agents. In vitro evaluation against clinical isolates of colistin-resistant Acinetobacter baumannii," Bioorganic and Medicinal Chemistry Letters, vol. 30, no. 18, Article ID 127411, 2020.

[4] S. Mazzotta, J. A. Marrugal-Lorenzo, M. Vega-Holm et al., "Optimization of piperazine-derived ureas privileged structures for effective antiadenovirus agents," European Journal of Medicinal Chemistry, vol. 185, Article ID 111840, 2020.

[5] A. P. Saraswati, N. Relitti, M. Brindisi et al., "Spiroindolinecapped selective HDAC6 inhibitors: design, synthesis, structural analysis, and biological evaluation," ACS Medicinal Chemistry Letters, vol. 11, no. 11, pp. 2268-2276, 2020.

[6] N. Relitti, A. P. Saraswati, G. Chemi et al., "Novel quinolonebased potent and selective HDAC6 inhibitors: synthesis, molecular modeling studies and biological investigation," European Journal of Medicinal Chemistry, vol. 90, Article ID 112998, 2020.

[7] S. Mazzotta, L. Frattaruolo, M. Brindisi et al., "3-Aminoalkylated indoles: unexplored green products acting as antiinflammatory agents," Future Medicinal Chemistry, vol. 12, no. 1, pp. 5-17, 2020.

[8] S. Shafi, M. Mahboob Alam, N. Mulakayala et al., "Synthesis of novel 2-mercapto benzothiazole and 1,2,3-triazole based bisheterocycles: their anti-inflammatory and anti-nociceptive activities," European Journal of Medicinal Chemistry, vol. 49, pp. 324-333, 2012.

[9] G. Grover, R. Nath, R. Bhatia, and M. J. Akhtar, "Synthetic and therapeutic perspectives of nitrogen containing heterocycles as anti-convulsants," Bioorganic and Medicinal Chemistry, vol. 28, no. 15, Article ID 115585, 2020.

[10] M. M. Heravi and V. Zadsirjan, "Prescribed drugs containing nitrogen heterocycles: an overview," RSC Advances, vol. 10, no. 72, pp. 44247-44311, 2020.

[11] S. S. Gholap, "Pyrrole: an emerging scaffold for construction of valuable therapeutic agents," European Journal of Medicinal Chemistry, vol. 110, pp. 13-31, 2016. 
[12] D. D. Xuan, "Recent progress in the synthesis of pyrroles," Current Organic Chemistry, vol. 24, no. 6, pp. 622-657, 2020.

[13] A. Sharma and P. Piplani, "Microwave-activated synthesis of pyrroles: a short review," Journal of Heterocyclic Chemistry, vol. 54, no. 1, pp. 27-34, 2017.

[14] S. Ahmad, O. Alam, M. J. Naim, M. Shaquiquzzaman, M. M. Alam, and M. Iqbal, "Pyrrole: an insight into recent pharmacological advances with structure activity relationship," Elsevier Masson SAS, vol. 157, 2018.

[15] H. Kuznietsova, N. Dziubenko, I. Byelinska et al., "Pyrrole derivatives as potential anti-cancer therapeutics: synthesis, mechanisms of action, safety," Journal of Drug Targeting, vol. 28 , no. 5, pp. 547-563, 2020.

[16] Q. Zhou, L. Jia, F. Du et al., "Design, synthesis and biological activities of pyrrole-3-carboxamide derivatives as EZH2 (enhancer of zeste homologue 2) inhibitors and anticancer agents," New Journal of Chemistry, vol. 44, no. 6, pp. 2247-2255, 2020.

[17] J. Ji, F. Sajjad, Q. You et al., "Synthesis and biological evaluation of substituted pyrrolidines and pyrroles as potential anticancer agents," Archiv der Pharmazie, vol. 353, Article ID e2000136, 2020.

[18] F. Aiello, A. Garofalo, and F. Grande, "Direct cyclization of ortho-(1H-pyrrol-1-yl)aryl and heteroaryl carboxylic acids into fused pyrrolizinones," Tetrahedron Letters, vol. 51, no. 50, pp. 6635-6636, 2010.

[19] F. Aiello, A. Garofalo, and F. Grande, "Convenient synthesis of fluorazone derivatives by one-pot pyrrolation/cyclization of anthranilic acids," Tetrahedron Letters, vol. 52, no. 44, pp. 5824-5826, 2011.

[20] F. Aiello, A. Garofalo, and F. Grande, "Efficient synthesis of 9H-pyrrolo[1,2-a]indol-9-one derivatives based on active manganese dioxide promoted intramolecular cyclization," Tetrahedron, vol. 66, no. 1, pp. 274-277, 2010.

[21] F. Grande, A. Brizzi, A. Garofalo, and F. Aiello, "Active manganese dioxide promoted cyclization of ortho- $(1 \mathrm{H}-\mathrm{pyr}-$ rol-1-yl)aryl and heteroaryl carboxylic acids to 5H-pyrrolo [1,2-a][3,1]benzoxazin-5-one derivatives," Tetrahedron, vol. 69, no. 47, pp. 9951-9956, 2013.

[22] M. Badolato, G. Carullo, F. Aiello, and A. Garofalo, "Synthesis and experimental validation of new PDI inhibitors with antiproliferative activity," Journal of Chemistry, vol. 2017, 2017.

[23] M. Badolato, G. Carullo, B. Armentano, S. Panza, R. Malivindi, and F. Aiello, "Synthesis and anti-proliferative activity of a small library of 7-substituted 5H-pyrrole [1,2-a] $[3,1]$ benzoxazin-5-one derivatives," Bioorganic and Medicinal Chemistry Letters, vol. 27, no. 14, pp. 3092-3095, 2017.

[24] L. Greene, S. Butini, G. Campiani, D. Williams, and D. Zisterer, "Pre-clinical evaluation of a novel class of anticancer agents, the Pyrrolo-1, 5-benzoxazepines," Journal of Cancer, vol. 7, no. 15, pp. 2367-2377, 2016.

[25] M. Brindisi, C. Ulivieri, G. Alfano et al., "Structure-activity relationships, biological evaluation and structural studies of novel pyrrolonaphthoxazepines as antitumor agents," European Journal of Medicinal Chemistry, vol. 162, pp. 290-320, 2019.

[26] F. Grande, F. Aiello, O. D. Grazia, A. Brizzi, A. Garofalo, and N. Neamati, "Synthesis and antitumor activities of a series of novel quinoxalinhydrazides," Bioorganic and Medicinal Chemistry, vol. 15, no. 1, pp. 288-294, 2007.

[27] M. Perri, F. Aiello, E. Cione et al., "Investigation of TNBC in vitro antiproliferative effects of versatile pirrolo[1,2-a] quinoxaline compounds," Frontiers in Molecular Biosciences, vol. 6, pp. 1-5, 2019.

[28] F. Aiello, G. Carullo, F. Giordano et al., "Identification of breast cancer inhibitors specific for $G$ protein-coupled estrogen receptor (GPER)-Expressing cells," ChemMedChem, vol. 12, no. 16, pp. 1279-1285, 2017.

[29] E. D. Morgan, "Vogel's textbook of practical organic chemistry. 5th edn," Endeavour, vol. 14, no. 3, p. 148, 1990.

[30] C. C. Cheng, X. Huang, G. W. Shipps et al., "Pyridine carboxamides: potent palm site inhibitors of HCV NS5B polymerase," ACS Medicinal Chemistry Letters, vol. 1, no. 9, pp. 466-471, 2010.

[31] E. A. Ariazi, E. Brailoiu, S. Yerrum et al., "The G proteincoupled receptor GPR30 inhibits proliferation of estrogen receptor-positive breast cancer cells," Cancer Research, vol. 70, no. 3, pp. 1184-1194, 2010.

[32] A. Holm, B. Baldetorp, B. Olde, L. M. F. Leeb-Lundberg, and B.-O. Nilsson, "The GPER1 agonist G-1 attenuates endothelial cell proliferation by inhibiting DNA synthesis and accumulating cells in the S and G2 phases of the cell cycle," Journal of Vascular Research, vol. 48, no. 4, pp. 327-335, 2011.

[33] Q. K. Y. Chan, H.-M. Lam, C.-F. Ng et al., "Activation of GPR30 inhibits the growth of prostate cancer cells through sustained activation of Erk1/2, c-jun/c-fos-dependent upregulation of p21, and induction of G2 cell-cycle arrest," Cell Death and Differentiation, vol. 17, no. 9, pp. 1511-1523, 2010.

[34] X. Lv and C. Wang, "G-1: new potential therapeutic option for ovarian cancer," Cancer Cell Microenvironment, vol. 1, pp. 17-19, 2014.

[35] J.-Q. Chen and J. Russo, "ER $\alpha$-negative and triple negative breast cancer: molecular features and potential therapeutic approaches," Biochimica et Biophysica Acta (BBA)-Reviews on Cancer, vol. 1796, no. 2, pp. 162-175, 2009. 